I mproving Short Story Reading Skills with P2R Method and ThinkingPaired-Sharing Models for Class IX Students of SMP Negeri 1 Poto Tano Academic Year 2019/ 2020

\title{
Peningkatan Keterampilan Membaca Cerpen dengan Metode P2R dan Model Berpikir-Berbasangan-Berbagi pada Siswa Kelas IX SMP Negeri 1 Poto Tano Tahun Pelajaran 2019/ 2020
}

\section{Dra. Seni Hadiawati}

email: seni.watihadia232@gmail.com

\begin{abstract}
Short story reading skills of grade IX students of SMP Negeri 1 Poto Tano are still low. This is because students find it difficult to retell the contents of short stories and find intrinsic elements in short stories. This is due to the use of approaches and learning media that are less interesting and boring. In addition, the teacher has not been intensive to guide students in learning to read short stories. Based on the results of this action research shows that using the P2R method and thinking-pair-sharing models in reading short stories in class IX students with $100 \%$ completeness, thus reading short stories with the P2R method and thinking-pair-sharing models in class IX students of SMP Negeri 1 Poto Tano is good.
\end{abstract}

\begin{abstract}
Abstrak: Keterampilan membaca cerpen siswa kelas IX SMP Negeri 1 Poto Tano masih rendah. Hal tersebut disebabkan siswa merasa kesulitan dalam menceritakan kembali isi cerpen dan menemukan unsur-unsur intrinsik dalam cerpen. Hal ini disebabkan penggunaan pendekatan dan media pembelajaran kurang menarik dan membosankan. Selain itu, guru belum secara intensif untuk membimbing siswa dalam pembelajaran membaca cerpen. Berdasarkan hasil penelitian tindakan ini menunjukan bahwa menggunakan metode P2R dan model berpikir-berpasangan-berbagi dalam membaca cerpen pada siswa kelas IX dengan ketuntasan mencapai $100 \%$, dengan demikian membaca cerpen dengan metode P2R dan model berpikir-berpasangan-berbagi pada siswa kelas IX SMP Negeri 1 Poto Tano dangan baik.
\end{abstract}

Keywords: Skill, Short Story Reading, P2R Method, ThinkingCouple-Sharing-Models.

Kata Kunci : Keterampilan, Membaca Cerpen, Metode P2R, Model Berpikir-Berpasangan-Berbagi. 


\section{A. Latar Belakang}

Membaca adalah suatu proses yang dilakukan serta dipergunakan oleh pembaca untuk memperoleh pesan, yang hendak disampaikan oleh penulis melalui media kata-kata/bahasa. Membaca sebenarnya hakikatnya adalah melihat tulisan, menyuarakan atau tidak bersuara (membaca dalam hati) dan mengerti isi atau makna tulisan.

Dalam Kurikulum Tingkat Satuan Pendidikan (KTSP) Pembelajaran Bahasa Indonesia diarahkan untuk meningkatkan kemampuan peserta didik untuk berkomunikasi dalam bahasa Indonesia dengan baik dan benar, baik melalui lisan maupun tulis, serta menumpuhkan apresiasi terhadap hasil karya kesastraan manusia Indonesia. Hal ini peserta didik (siswa) dituntut untuk mampu mengembangkan potensi diri dalam berbahasa dan bersastra baik secara lisan maupun tulisan.

\section{Keterampilan Membaca Cerpen}

Keterampilan membaca sangat penting bagi siapa saja terutama bagi peserta didik atau pelajar. Keterampilan membaca tidak hanya sangat diperlukan bagi sekolah menengah maupun diperguruan tinggi melainkan setelah selesai perguruan tinggi dan bertuga dimanapun masih tetap diperlukan. Waller Pauk dari Universitas Carnell menggolongkan keterampilan membaca sebagai pokok yang terus-menerus diperlukan (The Basic On-Going Skill).

Berdasarkan pendapat para ahli, dapat disimpulkan bahwa membaca pemahaman adalah suatu kegiatan memahami pesan-pesan media tulis melalui beberap aspek di dalam wacana yang dipengaruhi oleh faktor eksternal dan internal pembaca. Sedangkan dalam membaca pemahaman membaca cerpen digunakan untuk memahami isi cerpen dan mengerti unsur-unsur intrinsik dalam cerpen.

\section{Pengertian Cerita Pendek}

Cerita pendek adalah wadah yang biasanya dipakai oleh pengarah untuk menyuguhkan sebagian kecil saja dari kehidupan tokoh yang paling menarik perhatian pengarang". J adi sebuah cerita senantiasa memusatkan perhatiannya pada tokoh utama dan permasalahannya yang paling menonjol dan menjadi tokoh cerita pengarang, dan juga mempunyai efek tunggul, karakter, alur dan latar yang terbatas. Cerpen memuat penceritaan kepada satu peristiwa pokok, peristiwa pokok itu tidak selalu "sendirian" ada peristiwa lain yang sifatnya mendukung peristiwa pokok.

\section{Unsur-Unsur Pembangun Cerpen}

Unsur-unsur dalam cerpen terdiri atas : tema, amanat, alur atau plot, tokoh dan penokohan, latar (setting), sudut pandang (point of view), dan gaya bahasa.

\section{a. Tema}

Cerpen harus mempunyai tema atau dasar. Dasar itu adalah tujuan dari cerpen itu, dengan dasar ini pengarang dapat melukiskan watak-watak dari orang yang diceritakan dalam cerpen itu dengan maksud yang

$$
\text { 2|Edisi } 2 \text { No.1 Januari } 2020
$$


tertentu, demikian juga segala kejadian yang dirangkaikan berputar pada dasar itu. Amiruddin (2002) tema adalah ide yang mendasari suatu cerita sehingga berperan juga sebagai pangkal tolak pengarang dalam memaparkan karya fiksi yang diciptakannya. Waluyo (2003) mengemukakan bahwa tema adalah gagasan pokok yang dikemukakan penyair melalui puisinya. Tema mengacu pada penyair. Pembaca sedikit banyak harus mengetahui latar belakang penyair agar tidak salah menafsirkan tema isi tersebut.

Menurut beberapa pendapat diatas, dapat disimpulkan bahwa tema merupakan dasar pemikiran yang melandasi suatu karya sastra. Melalui tema inilah pengarang mengungkapkan apa yang ia lihat, dengar, serta ia rasakan, sehingga dapat dinikmati oleh pemabaca.

\section{b. Amanat}

Waluyo (2003) mengungkapkan amanat, pesan, nasehat meruapakan kesan yang ditangkap pembaca setelah membaca cerpen. Amanat dirumuskan sendiri oleh pembaca. Dengan demikian dapat disimpulkan bahwa amanat meruapakan makna tersirat yang disampaikan penulis dalam cerpennya.

\section{c. Alur atau Plot}

Nurgiantoro (2005) menagatakan alur berkaitan dengan masalah urutan penyajian cerita beserta urutan kejadian yang memperlihatkan tingkah laku tokoh dalam aksinya. Suharianto (2005) mendefisikan alur sebagai jalinan peristiwa secara beruntun dalam sebuah prosa fiksi yang memperhatikan hubungan sebab akibat sehigga cerita itu meruapakan keseluruhan yang pada, bulat, dan utuh sehingga cerita tersebut menjadi indah.

\section{d. Tokoh dan Penokohan}

Amunudin (2009) berpendapat bahwa tokoh adalah pelaku yang mengemban peristiwa dalam cerita fiksi sehingga peristiwa itu mampu menjalin suatu cerita. Niko dan Rafa (2004) menyatakan tokoh adalah orang-orang dalam cerita. Menurut Jones (dalam Nurgiyanto 2002) penokohan adalah gambaran yang jelas tentang seseorang yang ditampilkan dalam sebuah cerita. Pengertian ini mengacu pada bagaimana cara pengarang memberikan perwatakan pada tokoh-tokoh ceritanya. Berdasarkan pendapat di atas dapat disimpulkan tokoh adalah individu rekaan pengarang yang bersifat fiktif yang mengemban peristiwa dalam ceritanya.

\section{e. Latar atau Setting}

Nugiantoro (2005) menyatakan bahwa latar adalah pijakan cerita secara konkret dan jelas. Hal ini penting untuk memberikan kesan realistis kepada pembaca, penciptakan suasana tertentu yang seolah-olah sungguhsungguh akan terjadi. Dengan demikian pembaca merasa dipermudah untuk mengapresiasikan daya imajinasinya, disamping itu dimungkinkan untuk berperan serta secara kritis. Menurut pendapat Aminddin (2004) membedakan dua buah latar, yaitu latar yang bersifat psikologis. Latar yaang bersifat fisikal adalah latar yang berhubungan dengan tempat,

$$
\text { 3|Edisi } 2 \text { No.1 Januari } 2020
$$


misalnya kota Taliwang, daerah kumuh, sungai, pasar, serta benda-benda dalam lingkungan tertentu yang tidak menuansakan makna apa-apa. Latar atau sitting adalah peristiwa dalam karya fiksi, baik berupa tempat, waktu, maupun peristiwa, serta memiliki fungsi fisikal dan fungsi psikologis (Aminuddin 2004). Abrams (dikutip oleh Nurgiyanto 2005).

\section{f. Sudut Pandang (point of view)}

Sudut pandang merupakan cara memandang yang digunakan pengarang sebagai sarana untuk menyajikan tokoh, tindakan, latar, dan sebagai peristiwa yang berbentuk cerita (Suharianto 2005). Pada hakikatnya sudut pandang merupakan strategi, teknik, atau siasat yang secara sengaja dipilih pengarang untuk mengemukakan gagasan dalam ceritanya (Haryati 2007). Barhin (1985), sudut pandang dibagi menjadi dua yaitu sudut padang orang pertama dan sudut pandang orang ketiga. Sudut pandang orang pertama yaitu pencerita sebagai salah satu tokoh dalam cerita dan dalam terkisah mengacu pada dirinya dengan sebutan aku atau saya. Apabila dalam cerita pencerita bertindak sebagai tokoh utama disebut sudut pandang orang pertima akuan sertaan, sedangkan apabila pencerita menjadi tokoh bawahan disebut sudut pandang orang pertama akuan sertaan.

\section{g. Gaya Bahasa}

Suharianto (2005) mengatakan bahwa gaya bahasa dalam karya sastra mempunyai fungsi ganda yaitu sebagai alat penyampaian maksud pengarang dan sebagai penyampaian perasaan. Artinya, melalui karya sastra seorang pengarang bukan hanya sekedar bermaksud memberitahukan kepada pembaca mengenai apa yang dilakukan dan dialami tokoh dalam ceritanya, melainkan bermaksud pula untuk mengajak pembacanya untuk ikut merasakan apa yang dilakukan oleh tokoh cerita. Haryati (2007) mendefinisikan gaya merupakan cara mengungkapkan seseorang yang khas atau gaya adalah cara pemakaian bahasa yang khas oleh seseorang pengarang.

\section{Metode P2R}

Metode P2R dalam pembelajaran yang dilakukan dalam beberapa tahap, yaitu pertama apa yang diharapkan, dimaksud atau apa tujuan pembaca, kedua yaitu rencana untuk mencapai tujuan. Tujuan yang sudah dirumuskan diusahakan untuk dicapai. Pada tahap ini pembaca menyusun trategi untuk mencapai tujuan membaca. Rencana yang dibuat berhubungan dengan teknik baca yang digunakan, bagian-bagian yang akan dibaca, rencana-rencana lainnya (misalnya mempersiapkan pensil untuk memberikan tanda atau catatan), ketiga yaitu pelaksanaan membaca. Metode P2R merupakan metode membaca yang terdiri atas tahap preview, read, dan review yang biasanya digunakan sebagian besar pembaca cepat dan efesien (Gordon, 2006). Ketiga tahapan dalam metode ini tidak harus digunakan semua secara tertib. Hal tersebut tergantung pada situasinya.

\section{Model Berpikir-Berpasangan-Berbagi}

Model berpikir-berpasangan-berbagi merupakan salah satu model pembelajaran inovatif yang berbasis kooperatif aatu kerjasama. Model ini

$$
\text { 4|Edisi } 2 \text { No.1 Januari } 2020
$$


memberi siswa kesempatan untuk bekerja sendiri serta bekerja sama dengan orang lain.. Model ini pertama kali dikembangkan oleh Frank Lyman dari Universitas Maryland pada tahun 1985 (Think-Pair-Share) sebagai struktur kegiatan pembelajaran gotong-royong. Model ini memberikan siswa kesempatan untuk bekerja sendiri dan bekerjasama dengan orang lain. ThinkPair-Share) atau berpikir-berpasangan-berbagi memiliki prosedur yang ditetapkan secara eksplisit untuk memberikan siswa waktu lebih banyak untuk berpikir, menjawab, dan saling membatu satu sama lain. Model Think-PairShare sebagai dari tanya jawab seluruh kelas (Anita Lie, 2010:57).

\section{Pembelajaran Membaca Cerpen dengan Metode P2R dan Model Berpikir-Berpasangan-Berbagi}

Pembelajaran adalah sesuatu yang dilakukan oleh guru, sehingga tingkah laku siswa berubah ke arah yang lebih baik. Kegiatan membaca memerlukan pemusatan perhatian, kesempatan dan ketepatan. Oleh karena itu, membaca dilakukan secara sadar dan berkemauan. Untuk menghasilkan keefektifan dalam pemahaman dan kemampuan membaca cerpen dapat menggunakan model dan teknik pembelajaran yang tepat (Darsono dan Mufarichah 2006:33).

\section{B. Metode Penelitian}

Penelitian ini menggunakan desaian (PTK) dengan dua siklus, yaitu proses tindakan pada siklus I dan siklus II, setiap siklus dilaksanakan melalui empat tahap. Empat tahap ini adalah tahap perencanaan, tindakan, pengamatan, dan refleksi. Berikut bagian bagan untuk menggambarkan rangkaian siklus dan masing-masing tahapnya.

Penelitian tindakan kelas ini dilakukan dua siklus. Siklus I dilakukan untuk mengetahui keterampilan membaca cerpen pada tahap awal tindakan penelitian. Siklus ini sekaligus digunakan sebagai refleksi untuk melakukan siklus II. Siklus II digunakan untuk mengetahui peningkatan keterampilan membaca cerpen setelah dilakukan perbaikan-perbaikan terhadap pelaksanaan proses belajar mengajar yang didasarkan pada siklus I. Namun sebelum diadakan siklus I, obeservasi awal dilakukan agar dapat mengetahui kondisi seiwa di dalam kelas dan kesulitan-kesulitan apa saja yang dialami oleh siswa.

Sedangkan Subjek dalam penelitian ini adalah Kelas IX SMP Negeri 1 Poto Tano dalam membaca cerpen. Peneliti meilih kelas IX SMP Negeri 1 Poto Tano sebagai subjek peneliti karena faktor-faktor berikut : (1) keterampilan membaca pemahaman teks cerpen kelas IX berdasarkan tes prasiklus hasilnya masih rendah, (2) siswa kelas IX SMP Negeri 1 Poto Tano, (3) adanya perilaku negatif yang ditunjukkan siswa kelas IX dalam pembelajaran membaca cerpen

Penelitian ini menggunakan dua teknik pengumpulan data, yaitu teknik tes dan teknik nontes.

\section{Hasil Penelitian}

Hasil penelitian ini diperoleh dari hasil tes dan nontes selama penelitian berlangsung. Hasil tes meliputi hasil pembelajaran keterampilan membaca cerpen dengan metode P2R dan model berpikir-berpasangan-berbagi pada

$$
\text { 5|Edisi } 2 \text { No.1 Januari } 2020
$$


siklus I dan siklus II. Hasil tes siklus I merupakan kondisi awal siswa membaca cerpen dengan metode P2R dan model berpikir-berpasangan-berbagi.

\section{Prasiklus}

Prasiklus merupakan kondisi sebelum siswa diberi tindakan dengan metode P2R dan model berpikir-berpasangan-berbagi dalam pembelajaran membaca pemahaman cerpen untuk menemukan unsur intrinsik. Kegiatan prasiklus dilakukan untuk mengetahui kemampuan awal siswa dalam membaca pemahaman cerpen untuk menceritakan kembali isi cerpen dan menemukan unsur intrinsik. Kegiatan Prasiklus ini diikuti oleh seluruh siswa kelas IX SMP Negeri 1 Poto Tano yang berjumlah 26 siswa. Hasil dari kegiatan pratindakan ini berupa data tes. Data tersebut dijelaskan lebih rinci dalam hasil tes prasiklus.

\section{Hasil Penelitian Siklus I}

Penelitian membaca cerpen dengan metode P2R dan model berpikirberpasangan-berbagi dua siklus, yaitu siklus I dan siklus II. Tindakan pada siklus I ini dilaksanakan sebagai salah satu upaya mengatasi permasalahan dalam pembelajaran kemampuan menganalisis unsur intrinsik dalam cerpen siswa kelas IX SMP Negeri 1 Poto Tano. Penelitian siklus I dilaksanakan sekali pertemuan, pertemuan pertama dilaksanankan untuk menyampaikan materi tentang cerpen dan unsur intrinsik cerpen. Pada setiap siklus, pelaksanaan tindakan dilakukan sekali pertemuan, setiap kali pertemuan terdiri atas dua jam pelajaran yang setiap jamnya adalah 40 menit.

\section{Hasil Penelitian Siklus II}

Tindakan siklus II dilakukan karena pada siklus I pembelajaran keterampilan membaca cerpen belum menacapai target yang diharapkan. Kriteria pada siklus II yaitu siswa dapat membaca cerpen dengan menggunakan metode P2R dan model berpikir-berpasangan-berbagi dengan target ketuntasan nilai 70 dengan kategori baik. Selain itu, masih terdapat perilaku dalam membaca cerpen masing tergolong kategori cukup, namun belum tampak perubahan berarti. Oleh karena itu, tindakan siklus II dilakukan untuk meningkatkan ketermapilan membaca cerpen dan mengubah perilaku siswa dalam belajar.

\section{Pembahasan}

Pembahasan hasil penelitian membaca cerpen dengan metode P2R dan model berpikir-berpasangan-berbagi ini didasarkan pada siklus I dan hasil tindakan siklus II. Penelitian tindakan kelas ini dilaksanakan melalui dua tahap, yaitu siklus I dan siklus II. Pembahasan hasil penelitian meliputi proses pembelajaran keterampilan membaca cerpen, peningkatan keterampilan membaca cerpen, dan perubahan tingkah laku siswa setelah dilakukan pembelajaran membaca cerpen, dan perubahan tingkah laku siswa setelah dilakukan pembelajaran membaca cerpen dengan metode P2R dan model berpikir-berpasangan-berbagi. Pembahasan proses pembelajaran mencakup segala aktivitas di kelas ketika pembelajaran membaca cerpen dengan metode P2R dan model berpikir-berpasangan-berbagi. Peningkatan keterampilan membaca cerpen dapat dilihat dari hasil tes siklus I dan siklus II, sedangkan

$$
\text { 6|Edisi } 2 \text { No.1 Januari } 2020
$$


perubahan tingkah laku siswa setelah dilakukan pembelajaran membaca cerpen menggunakan strategi LIPIRTUP dapat dilihat dari hasil nontes siklus I dan siklus II.

\section{E. Kesimpulan}

Berdasarkan hasil analisis, rumusan masalah, dan pembahasan penelitian tindakan kelas ini, dapat disimpulkan sebagai berikut :

1. Proses Pembelajaran membaca cerpen dengan metode P2R dan model berpikir-berpasangan-berbagi siswa kelas IX SMP Negeri 1 Poto Tano sudah berjalan dengan baik dan lancar sesuai dengan rencana pelaksanaan pembelajaran (RPP).

2. Keterampilan membaca cerpen siswa kelas IX SMP Negeri 1 Poto Tano mengalami peningkatan setelah mengikuti pembelajaran membaca cerpen dengan metode P2R dan model berpikir-berpasangan-berbagi. Peningkatan itu terlihat dari hasil tes membaca cerpen antara siklus I dan siklus II. Pada siklus I diperoleh hasil rata-rata kelas sebesar 68,15 dalam kategori cukup.

3. Perilaku siswa kelas IX SMP Negeri 1 Poto Tano selama mengikuti pembelajaran membca cerpen dengan metode P2R dan model berpikirberpasangan-berbagi mengalami perubahan ke arah yang lebih positif. 


\section{Daftar Rujukan}

Aminuddin. 2004. Pengantar Apresiasi Sastra. Bandung : Sinar Baru Algensido Arikunto, Suharsini, dkk. 2006. Penelitian Tindakan Kelas. Bandung : Sinar Baru Algesindo.

Atmazaki. 1990. I Imu Sastra dan Terapan. Padang : Angkasa Raya.

Barimin, Raminah. 1985. Teori dan Apresiasi Prosa Fiksi, Semarang : KIP Semarang Press.

Firdaus, Sulfathur Z, dkk. 1986. Buku Materi Pokok Analisis dan Rangkuman Bacaan Sastra. J akarta : Universitas Terbuka.

Harjasarjana, Ahmad Selamet dan Yeni Mulyati. 1997. Membaca 2. Jakarta : Depdiknas.

Harjono, Sartinah. 1988. prinsip-Prinsip Pengajaran Bahasa dan Sastra. Jakarta : Depdikbud.

Hartono, Bambang. 2006. Panduan Penyusunan Kurikulum Tingkat Satuan Pendidikan (KTSP). Semarang.

Hastuti, Sri. 1996. Strategi Belajar Mengajar Bahasa Indonesia. Jakarta : Depdikbud.

Ibrahim, Muslim, dkk. 200. Pembelajaran Kooperatif. Surabaya : Univrsity Press.

Nico dan Rafa. 2004. Panduan Menulis Fiksi untuk Pemula. Yogyakarta : Platinum.

Nurgiyanto, Burhan. 1994. Teori Pengajaran Fiksi. Yogyakarta : Gajah Mada University Press

Ratna, Nyoman Kutha. 2004. Teori, Metode, dan Teknik Penelitian Sastra. Yogyakarta : Pustaka Roestiyah. 2001. Stratrgi Belajar Mengajar. J akarta : Rineka Cipta

Sudjana. 1998. Keterampilan Berbahasa Membaca-Menulis-Berbicara Untuk Mata Kuliah Dasar-Dasar Bahasa Indonesia. Jakarta : Depdikbud.

Susanto, Edy. 2019. "Building Image of Madrasah: MTs Strategy. Al-Kautsar in

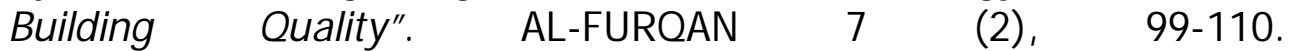
http://ejournal.kopertais4.or.id/sasambo/index.php/alfurqan/article/v iew/3458.

Marfuah. 2001. Peningkatan Pemahaman Cerita Pendek dengan Metode Pemberian Tugas Pada Siswa Kelas II SLTP N Bonang Kabupaten Demak Tahun Ajaran 2000/2001. Skripsi. Universitas Negeri Semarang. 